\title{
DEVELOPMENT OF REGIONAL PROGRAMS FOR THE DEVELOPMENT OF AGRARIAN ENTERPRISES WITH ORGANIC PRODUCTION ON THE BASIS OF THE EUROPEAN AND INTERNATIONAL EXPERIENCE
}

\author{
Mykola Ihnatenko' ${ }^{1}$ Natalia Novak ${ }^{2}$
}

\begin{abstract}
The objective of the article is to identify the problems of the development of organic agrarian production in Ukraine, to determine its resources, directions and instruments of state regulation and support (including on the basis of advanced European and world experience), as well as the preparation of regional development and improvement programs. Methodology. While the study, general scientific methods of scientific knowledge, as well as special methods of economic research were used. Monographic and historical methods were used in the analysis of stages of the formation and development of organic enterprises. Methods of problem-targeted approach, business planning, and investment planning were used in the preparation of organic farming and organic products development programs. Results. The article reveals the main results, trends, and problems in the development of organic agrarian production in Ukraine. There are presented positive examples of realization and distribution of its European and world experience, including on the principles of state regulation. Features, forms, and directions of state support of enterprises with organic production are determined. Means of its improvement were substantiated. The available and potential resources of the prospective development of organic production are determined. Regional programs of implementation of proposals have been developed on the example of Kherson region. Practical importance. It lies in the possibility of introducing the results in the organic enterprises of the country, in the bodies of management and regulation of agricultural production, in decisions of the rural communities on the development of organic production and organic products market, preservation of agrarian resources, environment, employment of rural residents. Scientific novelty. The state programs of organic production development are grounded on the basis of strengthening their regional, informational, and advisory components.
\end{abstract}

Key words: organic production, agriculture, enterprises, regional programs, state regulation, sustainable development, natural resources, ecology, market, improvement.

JEL Classification: Q15, P42, Q01, Q34, Q13

\section{Introduction}

European and world practice of organic agriculture witnesses its positive results not only in the aspect of realization of its direct functions but also in the development of rural economics and rural territories on the whole. Development of organic agriculture presupposes additional employment in a rural locality, new production perspectives for small farming economies, the rise of viability in rural communities, and other social benefits that are now so essential in Ukraine. Prospectively, organic farming and cattle breeding would allow for conformity and harmonization of social-economic and production-ecological goals of national agrarian enterprises. Looking back at the world experience, it is fair to say that organic agriculture represents the practical realization of basic concepts of sustainable development.

Establishment of mechanisms of state regulation in the introduction of organic production technologies in Ukraine requires the provision of a broad partnership for the purpose of the union of interests and needs of interested parties. What it in the first place means is the involvement in active cooperation of agricultural producers and their associations, bodies of state management, private consultative companies, certifying bodies, consumer organizations, scientific and educational institutions. In the second place, it refers to non-government organizations engaged in the sphere

\footnotetext{
Corresponding author:

${ }^{1}$ Pereiaslav-Khmelnitskyi State Pedagogical University named after Hryhorii Skovoroda, Ukraine.

E-mail: professorignatenko@ukr.net

${ }^{2}$ Kherson State Agrarian University, Ukraine.

E-mail: ks18.info@sfs.gov.ua
} 
of ecology, institution-building, advisory activity, and development of strategies for the country's agroproduction.

At the same time, the analysis of the Ukrainian market of organic production is complicated by the unavailability of official statistics concerning the examination of organic enterprises. This is why the marketing research and the data from the reports of foreign experts who certified organic agrarian production were the major sources of information.

\section{The main results, trends, and problems in the development of organic agricultural production in Ukraine}

According to data available with the International Federation of Organic Agriculture Movements (IFOAM), the total area of Ukrainian agricultural lands under organic farming reached the value of almost 300 thousand ha in the last years. It is an essential figure, for it appeared that Ukraine surpassed some countries from Eastern Europe - EU newcomers where such farming was the priority within the joint agrarian policy of the European Union.

However, despite huge areas allotted for organic farming, the domestic market features negligible scale of national organic products for the end consumer. Moreover, such products are represented solely by plants - cereal crops and sunflower (nearly 60.0\% in the total structure). Introduction of organic production technologies in cattle breeding is connected with a number of problems, e.g., shortcomings in expenditure accounting, high product cost, the immaturity of the market outlet, and absence of state support. This is why the transition to organic cattle breeding is today a predominantly loss-making business.

The majority of enterprises that cultivate organic products are located in the southern (Odesa, Kherson regions), western (Chernivtsi, Ternopil, and Lviv regions) and central (Poltava region) regions of Ukraine. It is a spirit of the times that these enterprises participate in joint projects (with companies from, in the first place, Switzerland and Germany) of the introduction of an organic trend in agricultural production. The results of the study of agricultural organic commodity producers' performance show that the efficiency of management in organic agriculture to a great extent depends on the use of soil-protecting technologies, quality of seed materials and timely agro-technical measures.

Competent state bodies should provide their assistance in the research of market capacities and solution of marketing problems encountered by enterprises-organic producers who require complete and verified information as to consumers, their demands, and the market's elasticity. With no study of demand and supply, consumer needs and specificities of their behaviour, it seems impossible to analyse, plan, and control production and sales today, for information have become a powerful instrument in successful entrepreneurship, even more important than money, materials, equipment, and labour resources. Provision of the company with comprehensive and reliable information enhances its competitiveness and market perspectives.

However, many problems should be solved in Ukraine prior to the big-scale introduction of organic production of foods, and low level of ecological awareness in both producers and consumers of agricultural production seems to be among the most sensitive challenges (Ihnatenko, 2015). The group of problems related to weak ecological awareness should be added with the absence of courses in theory and practice of organic farming management in educational institutions of different levels of accreditation. Besides the lack of education and low ecological awareness, an unwillingness to overcome stereotypes (those that formed within a long period of agricultural intensification) is observed, as well as low innovation activity among sectoral managers and state regulatory officials.

\section{Features, forms, and directions of state support for enterprises with organic production}

Aiming to encourage farmers to introduce new forms of agricultural management and help them in a transitional period when financial losses are likely to occur, the governments in many countries provided such entrepreneurs with state financial support. For example, "organic" enterprises in Poland were additionally receiving in 2010 the equivalent of 127 USD per 100 ha of plough land, 42 USD per 1 ha of pastures (grasslands), and nearly 157 USD per 1 ha of perennial plantings. Besides, the government had partially compensated the cost of "organic" enterprises' certification. In Ireland, the farms of less than 3 ha are allowed with 242 euros/ha in a transitional period and 121 euros/ha upon acquiring the "organic" status. Agricultural producers working on lands of 3 to 40 ha are supported in the amount of 181 and 91 euros/ha correspondingly.

Lack of proper regulation in the market makes organic producers engage traditional outlets for agrarian food products with no mark-up received. It is a rather widespread practice when organic product certificate owners are represented by third companies that undertake its export. Geography of supply is predominantly concentrated in highly developed countries of Western Europe (Great Britain, the Netherlands, Germany, Switzerland), where the increasing demand for organic food significantly exceeds the offer (Marmul, Novak, 2016). The up-to-date sales opportunity investigations in Ukraine confirm the fact that a uniform chain of satisfaction of national consumers' demand for organic 
production (market investigations-productionprocessing-distribution-sales) is now broken. The situation urges the development of an efficient strategy of marketing that would provide for systemacity and balance among all market participants.

The absence of an efficient system of state regulation and organic agriculture poor finance and credit mechanism stay to be among the factors that affect the development of the market for organic production. Though the dynamics of the agrarian crediting is now much better (due to interest rates partial compensation from the state budget), the producers' needs in borrowings are not yet fully satisfied. To help increase financing of organic commodity producers, it seems necessary to seek for different sources and crediting resources such as bank and loan association credits, the supply of machinery on conditions of the financial lease or instalment plan, etc.

Analysing environmental factors, it was essentially important to predefine special raw material zones for organic production. According to national scientists, nearly 15 million ha of ecologically clear lands could have been allotted for the cultivation of organic production in Ukraine. The analysis of microfactors that effect on enterprise activity in the market of organic production allows for the conclusion that lack of information and additional costs for certification discourage the formation of infrastructure that would bring service to organic commodity producers (Kyrylov, 2013).

State regulation in the area of organic commodity production is believed to be necessary for the purpose of preservation of product's high quality in all stages of its advance to the end consumer. Besides, it is conditioned by high research intensity of production, market operators' needs in informational and consultative support, and availability of transitional (from common to organic agriculture) period of activity since likeliness of losses and even bankruptcy sharply increases.

Formation of the system of national, regional, and local (rural community) support should consider specificities of social mechanisms in economics and the level of social responsibility of agricultural business since this or that way they effect on such support's mechanisms and forms. Social environment and organization of production directly effect on the behaviour of social groups and, correspondingly, on their interests and activity results and, subsequently, on management and groups' status.

Thus, the state can regulate processes of agriculture ecologization through the correction of the behaviour of an interaction within different social groups of the population. It can be executed by way of active participation in people's spiritual and cultural life and in all spheres of social relations through the state and private partnership. The latter is supposed to help form ecological awareness, a new system of ecological values, standards, and rules in the society, ecological culture, education and upbringing, principles of public informing on ecological problems. It is when all these issues are considered we may proceed with the further organization of agro-sector, rural economics, and rural territories on the whole.

It should be emphasized that the majority of small and medium-sized farms are oriented towards profitmaking here and now. This is why they regard the introduction of organic farming to be disadvantageous, in the first place, due to objectively anticipated losses during the transitional period. In our opinion, organic farming is also restrained by the absence of clearly outlined legislative framework and infrastructure. Besides, development of organic agrarian production is affected by inefficient management in some enterprises and insufficient state regulation on the whole, as well as by lack of agricultural business' social responsibility (Fedorov, Khodakivska, Korchynska, 2011).

Legal economic and social activity in organic production urgently requires its legislative support that would regulate and define, in the first place, the procedure of certification of its types. Here we should note that State System of BioSafety in Creation, Testing, Transportation, and Use of Genetically Modified Organisms Act, Ukraine, adopted by the Supreme Council of Ukraine, was an essential step towards the provision of food safety of the country and ecological safety of its agriculture.

The law regulates relations between Ukrainian executive authorities, and producers/consumers of genetically modified organisms and products manufactured with the use of permitted technologies that guarantee biological and genetic safety. No organic farming in the world uses either genetically modified organisms (GMOs) or materials derived from them. According to EU legislation, farmers engaged in organic production are prohibited to apply GM-dropping (EG 834/07). Practical introduction of organic production should take place simultaneously with ecologization of the whole agricultural production, rural territories, and the whole rural mode of life.

On the national level, organic agricultural production is regulated by Water, Commercial, Land, Criminal, Customs, Tax, and Civil Codes of Ukraine, as well as by its Labour Code and Civil Defence Code. Beginning from 2010, Standards for Plants Optimal Proportion in Crop Rotation within Different Natural/Agricultural Regions, the Resolution of the Cabinet of Ministers of Ukraine, became an effective giving way to the onrush of organic production. It is this Resolution that regulates the structure of crop rotations and minimal periodicity of crop cultivation within a field. However, its practical observance is restrained by the technological and economic capacities of agricultural producers. That is, the Government has only suggested a limitation of producers' choice and capacities with no suggestion of economic conditions and resources to realize Resolution's provisions. 
The bases for the development of organic agrarian production are also regulated by the Organic Agricultural Commodity and Raw Material Production and Turnover Act, Ukraine, adopted on 3 September 2013, № 425-VII (Organic Agricultural Commodity and Raw Material Production and Turnover Act, Ukraine, 2013) and 2020 State Ecological Strategy Act, Ukraine, on 21 December 2010, № 2818-VI. The laws define legal and economic bases for organic agricultural products and raw materials production and turnover; measures to control and supervise such activity for the purpose of the provision of fair competition and proper functioning of the market for organic commodities. They also deal with improvement of the parameters of population's health, preservation of the environment, soil quality improvement, soils rational use, and the consumer's assurance in products and raw materials marked as organic.

Adoption of the aforesaid instruments was the evidence of positive changes in the institutional structure of organic movements and regulation of organic production. It resulted in a positive balance of the indices of social-economic rural development, one that provides for agricultural activity even in conditions of crisis. At the same time, the Organic Agricultural Commodity and Raw Material Production and Turnover Act, the law that is called to regulate the process of production of organic commodities has some significant defects since does not suggest the mechanism of organic producers' support even in the period of transition.

Unobstructed development of organic production awaits introduction of amendments into Organic Agricultural Commodity and Raw Material Production and Turnover Act; 2020 State Ecological Strategy Act; Food Products Safety and Quality Act; Agriculture's of Ukraine State Support Act; Agricultural Cooperation Act; Priorities in Innovation Activity Act; National Safety Act; Licensing and Certifying Bodies Act; Chicken Production and Market Act; Beef Production and Market Act; Pork Production and Market Act; Vegetable and Fruit Production and Market Act; Hop Growing and Market Act; Flax Production and Market Act; Sheep Production and Market Act; and Food Safety Act.

The Prices and Price Formation Act, Ukraine, should be added with provisions, or new such law should be adopted for agro-industry where price formation specificities in organic production are taken into account especially in the segment that is capable not only of providing for the country's food safety but for the people's social protection and lowering of technogenic environmental loads. Introduction of the adequate mechanism of price formation will require a great deal of legal work.

Conditions should be arranged for innovative development of agriculture and food industry in the fulfilment of Art 7, Priorities in Innovation Activity Act, Ukraine, where the highly technological development of agriculture and processing industry is recognized to be among prior strategic directions of innovation activity. At the same time, questions of infrastructure in the market for innovations in the agrarian sector and the introduction of organic agrarian technologies, that is, those that manifest friendliness towards the environment require legislative regulation.

Financial assurance is an important aspect in the development of organic agroproduction. It is with financial/crediting instruments, sanctions or preferences that the state encourages producers to undertake organic agriculture. Mechanisms of agroproducers' preferential crediting and taxation are aimed at the provision of access to financial resources and payment at the expense of income from borrowings. Besides, the preferential regime of taxation is supposed to stimulate producers for the introduction of innovations and cheapening of the end product for the consumers. The good effect is awaited from tax holidays for those who started the process of organic standard certification until they gain profit from sales of their certified organic commodities (Garmashov, Fomichiva, 2010).

Developing national and regional programs of organic production support, one should be aware that not only the producers and the consumers of organic products but also the state sector shall become the recipients of program results. Local authorities and state bodies should support producers and participate in such program in the capacity of third party performing as state/private partnership when agroproducers cooperate with international organizations and funds (Shpychak, 2003). State bodies' active position in questions of organic production is expected to speed up the investment component and provide for the functioning of the instruments of regulation and support.

Instruments of regulation should be preventive, that is, of precautionary character, and make producers apply organic technologies and strictly keep to technological process that would guarantee production of qualitative and safe commodities. Producers who cause harm by way of applying intense technologies and GMOs should additionally pay to special local funds of organic production support. Should the technological process be frustrated, the producer must be aware of its consequences that would take the form of penalties or certificate revocation. Major indicators of efficiency of financial/crediting and budgetary support of organic production must be as follows: dynamics of increase in production; consolidated budget revenue; employees' income and labour quality; environmental health and agro-landscapes preservation; level of insurance protection; investment volume and structure; credits accessibility; activity's financial results; social responsibility. 
The contraction of the scope of finance for scientific developments and the private enterprises' unwillingness to allow scientists to their activity, as well as the contraction of the number of state research enterprises has artificially separated science and production. The recipients' of advisory services readiness to cooperate with scientific institutions, share their own experience of problems solution, participate in scientific/production experiments, introduce innovative technologies and make investments would have been the evidence of the efficiency of the net of expansion of agrarian knowledge (Lupenko, 2013). Advisory activity in the agrarian sector as one of the instruments of the sector's state regulation is called to assist the development of rural territories, the increase in the level of incomes and betterment of producers and rural inhabitants' living standards at the expense of their acquirement of new competence. The economic component would have become an important element of the recipients' of advisory services decision-making.

Information support of organic production should be performed in two directions. The first shall be the information for the producers of organic commodities, the second - for the commodity consumers. Certifying companies, international certifying institutions, international organizations, organic producer associations, agricultural support cooperations that deal with organic production, organic product sale points, and organic commodity producers/consumers can themselves be sources of such information support. The role of the state, local authorities and rural communities lies in assistance to spreading of objective information concerning advantages of organic production and specificities of organic commodity price formation.

To help form institutional environment of the organic agroproduction, and taking into account the world experience, the Organic Agricultural Commodity and Raw Material Production and Turnover Act awaits to be supplemented with a number of other legal instruments that would establish and specify the rules for the management of organic agroproduction; the structure and competence of controlling and certifying bodies; the provisions for sales of organic production and products, etc. Sole availability of legal framework will not allow for the efficient functioning of the institutional environment, it cannot itself solve questions of marking, a collection of statistical import and export data, capacities of regional support of organic producers, local standardization on the basis of national standards, etc.

The world experience tells us that each state solves the abovementioned problems with consideration of the mentality of producers and consumers. Nomenclature of informational/consultative services in organic production begins with the formation of ecological awareness and youth's ecological education, and proceeds with the organization of illustrative educational/ experimental farms that keep to organic principles of organic production, conduction of "days of the field" and other measures (Skydan, Grynyshyn, 2013).

Formation of the system of organic production's state support should provide not only for its active development, organic commodity supply, and export of fine national competitive product but also raise preconditions for environmental improvements in rural territories and sustainable development of the economy on the whole. Implementation of state policy of assistance to the development of organic production through the legal framework, management and infrastructure improvements, state/private partnership and social responsibility of agrobusiness would allow for the access to international markets and resources and, therefore, positively effect on the social-economic modernization of Ukrainian agrarian sector.

\section{Available and potential resources for the long-term development of organic production}

The number of farmers producing organic commodities hugely increased in the world, as well as the number of people that consume their production. Hence, the number of those associated in the Participatory Guarantee Systems (PGS) increased. Terminology and conceptual framework of PGS initiative were for the first time developed on a roundtable for alternative certification of organic production in Brazil in 2004. The table was organized by the International Federation of Organic Agriculture Movements (IFOAM) and the Latin America Agro-Ecology Movement (MAELA).

According to IFOAM, the PGS represent locally concentrated systems for the provision of quality. The systems unite producers and consumers on the basis of active participation of interested parties, and base on confidence, social links, and knowledge exchange. PGS-initiatives manifest themselves within the limits of national borders and are conditioned by formal and informal reasons. In particular, the PGS worldwide spreading was so quick and easy due to the cheap mechanism (no official certification required) of consumer's supply with organic production by small farming economies.

If we take the example of the Development of Organic Market in Ukraine, a 2012-2016 Swiss-Ukrainian project realized by the Research Institute of Organic Agriculture (FiBL, Switzerland), the PGS there was understood as a "system of quality guarantee focused on local development” (Chudovska, 2013). According to estimations, there exist at least 41 PGS initiatives in the world today, which covered all continents, and nearly the same number is in the process of development. Asia and Latin America still remain leaders in the number of PGS-certified farmers, as well as take the lead in PGS recognition by their national governments.

The FAO dictionary indicates that PGS represents a system of collective guarantees. Systems of collective 
guarantees have common aims with systems of certification by third parties (e.g., Organic Standard, PLC, in Ukraine) in the aspect of the provision of reliable guarantees for organic commodity consumers. At the same time, there exists an essential difference between PGS and traditional certification of organic production. As it appears from dictionary interpretation, direct participation of farmers and even consumers in the process of administration of guarantees within the PGS initiative is not simply welcomed but necessary.

Such participation is realistic when this refers to small farms and local markets where PGS initiatives are introduced. Active involvement of all interested parties results not only in their increased capacity but in an increase of responsibility, too. This is why PGS initiatives emphasize the growth of knowledge and competence not only among producers but also consumers. The PGS is not yet admitted on the level of organic production international trade but is important for the development of domestic markets inclusive of Ukrainian.

According to data available with the IFOAM, over 109,0 thousand producers and processors in the world are involved in PGS-initiatives, and 46,9 thousand of them are certified. PGS-initiatives are spread in 72 countries where 20 countries apply well-developed or those to be soon-introduced PGS-practices, 33 countries demonstrate only some applications of PGS, and 19 countries apply PGS only partially. PGS initiatives developed independently in different countries and in different cultural contexts in response to problems encountered by producers of organic commodities. However, they do possess a number of common and mandatory attributes, which are the availability of standards and norms; clearly established instalments; documented systems and procedures of management; mechanisms of conformity control; guarantees and marking; a system of penalties.

Guided by its own developments, the IFOAM assesses producers for the compliance with PGS principles and demands imposed on organic production and, if the result is positive, permit to use its official logo. Save for commodities, the logo can be used in websites, brochures, and advertising.

Thus, the PGS systems do not only guarantee the reliability of organic production but powerfully use local and alternative channels of sale. Despite different methodologies and strategies, the observance of basic principles refers them to one and the same community. The PGS base on norms developed by interested parties and include democracy and solidarity of the process; opportunity of its use by small farms; principles and values that add to provision of means of living and wealth for farmers' families and contribute to the spreading of organic agriculture; documented systems and procedures of management; mechanisms of farmers' observance of established standards; the interested parties' activation for the purpose of education with respect to said standards; mechanisms of farmers' support in production of organic commodities and recognition of their belonging to organic sector; signs or markings that confirm organic status; clearly pronounced consequences of standards and norms non-observance.

Organic technologies take an important place among innovative eco-developments since are capable of providing the present-day agrobusiness with biological means of agricultural product protection; biofertilizers; biotechnologies of vegetable forage production in cattle breeding; means of bio-remediation, bio-degradation and bio-conversion of wastes, etc. Unfortunately, since modern market of organic technologies is in its initial stage, there exists a problem of informational and financial support of organic innovation developers and providers who need instruments that would make their products and services more recognizable (inclusive of such intellectual property assets as know-how) for the purposes of sales and licensing.

Modern inventors engaged in innovative projects in the organic sector, especially those who work in the developing countries, have a unique chance to make use of WIPO GREEN, a platform initiated in 2012 by the World Intellectual Property Organization (WIPO) in cooperation with the other sectoral partners.

The WIPO GREEN aimed at the development of the mechanism to help unite owners of new ecooriented ("green") technologies and private individuals or companies interested in their commercialization and transfer. Upon successful testing of experimental database of licensing and sales-ready eco-innovations, an official start was given in November 2013 to a net that now provides for immediate spreading of the technologies of energy saving, energy alternative sources, new ecotransport types, new ecological forms of agriculture and forestry, etc. in all regions of the world.

The success shown by the WIPO GREEN is explained by their firm observance of the principles of transparency (openness of global store of technologies); synergism in partnership relations (freewill union of state and private sectors for the purpose of simplification of common work, quickening of investments and facilitation of mutually beneficial commercial operations); protection of intellectual property rights (guarantee of economic stimuli for development of new technologies).

The WIPO GREEN is represented by two components: 1) the database, which is the catalogue of disclosed needs and assets of intellectual property classified according to 9 directions: Agriculture and Forestry, Energy, Water, Pollution and Waste, Chemistry and Modern Materials, Transportation, Building and Construction, Green Products, Other Areas; and 2) the net, which is a global platform connecting users and encouraging partnership links.

As of 01 April 2016, the WIPO GREEN database indisposes information on any Ukrainian organic 
project though it is evident that the platform has a number of essential advantages, in particular: absence of customs duties for technology suppliers; operations' accompanying support, inclusive of registration of multi-jurisdictional patent application within the PCT and access to WIPO Arbitration and Mediation Center; 300 free hours of online-consulting for active registered users participating in operations connected with "green" technologies and whose projects aim to provide support for developing countries or whose goals serve the interests of the world.

We believe that registration of Ukrainian producers of organic technologies would help involve expert knowledge in the widest spectrum of application, inclusive of intellectual property management, licensing and investments, as well as it would be helpful in building commercial bridges by way of linkage between providers and those who seek for "green" organic technologies. It is in the first place important to organize adequate institutional infrastructure capable of integrating all participants of organic production development into a single mechanism; and arrange for their respective scientific/educational and informational/consultative provision.

\section{Regional programs of implementation of proposals on the example of the Kherson region}

Evolution of organic agriculture, the present-day trends in its development, increasing experience of the introduction of organic farming in a still greater number of farms is the evidence that alternative agricultural practices are a quite realistic and prospective business (Tikhonova, Mezhinskaya-Bruy, 2014). Organic production still encounters a number of problems that require their thorough analysis and subsequent efficient solution for the purpose of the provision of favourable conditions to its development. We see such problems to be as follows:

- the insufficiency of the respective regulatory environment, and inconsistency/incompleteness of the existing legal framework that regulates the activity of those engaged in organic production;

- the absence of adequate institutional-legal, financialeconomic, and social-psychological conditions necessary for the development of organic production; - the insufficiently developed infrastructure necessary to support organic production, and unavailability of tax preferences;

- low awareness among commodity producers, state bodies and local authorities as to opportunities and perspectives of organic production development;

- insufficient level of professional knowledge and experience among economic entities with respect to the management of organic production in presentday conditions and the absence of an efficient system of instruction of highly qualified experts in organic production.
To solve the aforesaid problems and in pursuance of 2020 State Strategy in Agricultural Industry, the Resolution of the Cabinet of Ministers of Ukraine No. 806-p as of 17 October 2013, where it was declared that state food safety will be achieved, food industry become highly efficient, agroproduction and food raise their competitiveness within domestic and international markets with simultaneous rise of rural employment, a Program of Organic Production Development in Kherson region was elaborated.

The Program's major aim lies in the arrangement of organizational/economic preconditions for economically efficient, competitive, socially and ecologically oriented development of the agrofood sector, population's stable provision with fine and safe food from national producers. Practical realization of Program's tasks and measures would add to rise of competitiveness among agricultural companies. Besides, external effects are expected, the ones that would appear due to and in the process of activity of organic entity in other subjects of the agricultural sector.

Among the external effects, we would accentuate on additional income to be gained by the processing industry; decrease in unemployment and social payments; growth of profits from rural green tourism, organic cattle breeding, bee-farming, and pond fishery; agricultural lands' cost increase; preservation of natural capital (Romaniuk, 2015). Realization of program measures would promote small and medium business; improve feedback between producers and consumers; help develop rural territories and local communities; contribute to the betterment of image and investment climate in the region, and facilitate its integration into national and world organic market.

Environmental benefits from the Program's realization are expected to be as follows: biological and landscape diversity, quality of soils and their functions, as well as water ecosystems, shall be preserved; ecological risks shall stay to be minimal; genetic fund of plants shall be preserved; the state of land resources and their reproduction shall become stable; newest ecological technologies shall be applied; ecological policy with respect to food safety shall improve; and pollutions from agricultural production especially those affecting water systems shall decrease.

\section{Conclusions}

Development and realization of the region-level "organic" programs is a vivid example of the realization of national and regional strategies for the development of farming involved in organic production. In particular, the realization of the Program of Organic Production Development in Kherson region and accomplishment of its tasks take place in the directions that would improve figures of economic activity of enterprises operating in the agrarian sector. The Program's realization is expected 
to significantly solve the problems of unemployment, rural communities' budget filling, the creation of new jobs, and improvement of the ecological situation.

The Program's major directions are as follows: 1) adjustment of organic production development's legal environment; 2) financial-crediting and investment support; 3) informational support; 4) formation of infrastructure to support the development of organic production; 5) conduction of scientific research and qualifications upgrade among the staff employed in organic production.

Realization of the measures suggested by the 2016-2020 Program is expected to result in the formation of favourable conditions for sustainable development of organic production in the region that would in its turn essentially contribute to the provision of regional food and ecological safety. Also, a synergic effect is awaited in the form of additional economic, social, and ecological benefits. Positive effects from the development of organic production shall take the form of increased incomes, enterprise competitiveness, decreased operation costs, and contraction of natureprotective payments.

At the same time, the external effects are expected, the ones that appear due to and in the process of activity of organic entity in other subjects of agricultural sector, in particular, additional income of processing industry; decrease in figures of unemployment and social aid payments; growth if profits gained from green tourism, organic cattle breeding, bee-farming; strengthening of living standards; increase of agricultural lands' cost. Realization of program measures would promote small and medium business; improve feedback between producers and consumers; help develop rural territories and local communities; contribute to the betterment of image and investment climate in the region; facilitate the integration of the Kherson region into the international organic market.

\section{References:}

Ihnatenko, M. M. Upravlinnya orhanichnym vyrobnytstvom ahrarnykh pidpryyemstv na zasadakh zdiysnennya sotsialnoyi vidpovidalnosti [Management of organic production of agrarian enterprises on the basis of social responsibility]. Economics and Finance, vol. 12, pp. 4-11.

Marmul, L. O., Novak, N. P. (2016). Rozvytok orhanichnoho vyrobnytstva v Ukrayini [Development of Organic Production in Ukraine]. Economics of Agro-Production Complex, vol. 9, pp. 26-32.

Kyrylov, Yu. E. (2013). Problemy ta perspektyvy rozvytku orhanichnoho vyrobnytstva v Ukrayini [Problems and perspectives of organic production in Ukraine]. Proceedings of the Orhanichne vyrobnytstvo i prodovolcha bezpeka (Ukraine, Zhytomyr, April 19, 2013), Zhytomyr: "Polissya", pp. 53-57.

Fedorov, M. M., Khodakivska, O. V., Korchinskaya, S. G. (2011). Rozvytok orhanichnoho vyrobnytstva [Development of organic production]. Kyiv: In-t agrar. Economics. (in Ukrainian)

Pro vyrobnytstvo ta obih orhanichnoyi silskohospodarskoyi produktsiyi ta syrovyny: Zakon Ukrayiny [Organic Agricultural Commodity and Raw Material Production and Turnover: Act Ukraine]. Retrieved from: http://zakon4.rada.gov.ua/laws/show/425-18 (accessed 24 June 2018)

Garmashov, V. V., Fomichova, O. V. (2010). Do pytannya orhanichnoho silskohospodarskoho vyrobnytstva v Ukrayini [On the issue of organic agricultural production in Ukraine]. Bulletin of Agrarian Science, vol. 7, pp. 11-16. Shpichak, O. M. (2003). Obgruntuvannya tsiny na ekolohichno "chystu" produktsiyu [Substantiation of the price for ecologically "pure" products]. Ekonomichnyy dovidnyk ahrarnyka [Economic directory of agrarist] (Ed. Luzana Yu.A., Sabluk P.G.). Kyiv: Press of Ukraine, pp. 309-310.

Lupenko, Yu. O. (2013). Formuvannya popytu ta propozytsiyi na rynku orhanichnoyi produktsiyi [Formation of demand and supply in the market of organic products]. Proceedings of the Orhanichne vyrobnytstvo $i$ prodovolcha bezpeka (Ukraine, Zhytomyr, April 19, 2013), Zhytomyr: "Polissya", pp. 3-9.

Skidan, O. V., Grinishyn, V. E. (2013). Prohramuvannya rozvytku orhanichnoho vyrobnytstva v rehioni [Programming of organic production development in the region]. Proceedings of the Orhanichne vyrobnytstvo $i$ prodovolcha bezpeka (Ukraine, Zhytomyr, April 19, 2013), Zhytomyr: "Polissya", pp. 30-36.

Chudovskaya, V. A. (2013). Formuvannya tsiny na orhanichnu silskohospodarsku produktsiyu v rynkovykh umovakh [Formation of prices for organic agricultural products in market conditions]. Economics of Agro-Production Complex, vol. 1, pp. 142-146.

Tikhonova, N. O., Mezhinskaya-Bruy, O. Yu. (2014). Orhanichna produktsiya: perevahy i nedoliky [Organic products: advantages and disadvantages]. Scientific works of NUKHT, vol. 5, no. 20, pp. 9-14.

Romaniuk, I. A. (2015). Osnovni chynnyky ta napryamy intensyfikatsiyi ahrarnoho vyrobnytstva v suchasnykh umovakh hospodaryuvannya [Main factors and directions of intensification of agrarian production in modern economic conditions]. Scientific works of PDAA, vol. 2(11), pp. 225-230. 